\title{
Introduction to the special issue on SFB 574 "Volatiles and fluids in subduction zones: climate feedback and trigger mechanisms for natural disasters"
}

\author{
A. Freundt • R. Halama $\cdot$ E. Suess $\cdot$ D. Völker
}

Published online: 23 July 2014

(C) Springer-Verlag Berlin Heidelberg 2014

Sonderforschungsbereiche (SFBs) are a successful funding model in use by the German Science Foundation (DFG) for over 30 years to strengthen basic research first locally at universities and later also supra-regionally by including academic institutions at different cities and states. Literally translated, SFB means "special research area" that comprises research that complements but does not duplicate research at participating institutions and departments. The English terminology used by the DFG is "Collaborative Research Centre," which better describes the expected approach by emphasizing collaboration and interdisciplinary efforts in such a way that the overall result is better than the sum of individual results.

The SFB 574 had united more than 70 scientists with expertise in structural geology, geophysics, sedimentology, geochemistry, empirical and experimental petrology, volcanology, and biology for 11 years (2001-2012). The overarching theme addressed the role of volatiles in subduction zone tectonic, hydrological, metamorphic and magmatic processes, and resulting hazards. The main areas of research were the subduction zones of Central America and southern Chile. Both extend across shorelines from deepsea trenches to arc-volcano summits and thus required to

A. Freundt $(\bowtie) \cdot$ R. Halama $\cdot$ E. Suess $\cdot$ D. Völker

SFB 574 at Kiel University, Kiel, Germany

e-mail: afreundt@geomar.de

A. Freundt $\cdot$ E. Suess

GEOMAR, Kiel, Germany

R. Halama

University of Potsdam, Potsdam, Germany

D. Völker

MARUM, Bremen University, Bremen, Germany combine field work on land with marine cruises probing the seafloor.

During the course of the SFB 574, many different aspects of subduction zone processes were investigated. Geophysical investigations identified and quantified the input of water through hydration of the bend-faulted subducting plate as far as mantle depths. This process and water release from the subducting slab deeper in the subduction zone was investigated by numerical modeling. These studies highlighted the important role of hydration and dehydration of mantle rocks for the global water cycle. Subducted oceanic fracture zones are another conduit for water transported deep into the subduction zone.

Compactional and thermal dehydration of the subducted sediment layer affects the strength of interplate coupling and the depth and lateral extension of the seismogenic zone where disastrous earthquakes are generated. The fluids, largely generated by clay mineral transformation, are expelled through the forearc by splay faults. At the seafloor, the sites of cold seeps, often associated with mud volcanoes, are populated by biota that control the carbon transfer to the ocean. The most prominent manifestations of cold seeps are authigenic carbonates that form from anaerobic oxidation of methane and which serve as archives of forearc processes. The largest cold seep emissions occur at faults generated by the subduction of volcanic seamounts.

Petrological analyses of ancient, exhumed subduction zone metamorphic rocks revealed the important role of pervasive, typically channelized fluids in high-pressure metamorphic reactions of dewatering subducted igneous crust and mantle. Slab-derived fluids hydrate the mantle wedge along the slab-wedge interface and form a subduction channel in which mixing of different fluids and fluid-rock interaction causes metasomatic overprinting. The element redistributions associated with the liberation of fluids from 
the slab ultimately become apparent in magmatic compositions at the volcanic arc. Along- and across-arc geochemical variations have been systematically related to lithological compositions and water-carrying capacities of the subduction input. Lateral displacements between related input and output compositional characteristics supported geophysically observed mantle anisotropy in the recognition of trench-parallel mantle flow of similar magnitude than the conventionally envisioned corner flow in the mantle wedge.

Although geophysical imaging has demonstrated fluid pathways and possible storage zones outside the subarc root zone of the volcanoes, slab-derived fluids play a major role in the explosivity of arc volcanism, and in the long term, widespread tephras account for about half of the erupted magma mass. Both measurements of active degassing and statistical analyses of historic and geologic eruption records have been used by the SFB to assess volcanic hazards, and climate modeling has investigated the global atmospheric effects of volcanic emissions.

The present count of 252 published and 18 submitted peer-reviewed publications including book chapters and cruise reports shows that 2 years after the formal conclusion of the SFB 574, scientific results continue to be generated. The collected papers in this special volume touch on all aspects and the entire breadth of topics initially conceived by the sub-projects, e.g., input with the subducting plate, processes within the forearc and subarc regions, output through the volcanic arc, and seismic and volcanic hazards as briefly summarized above.

In this special volume, the first set of papers addresses forearc processes in the Central America and Chile subduction zones. The structure of the Central American subduction zone is addressed by Lücke using gravity data to image the distribution of crustal thicknesses across Central America. Arroyo et al. trace the extent of the seismogenic zone along Costa Rica where the subducted crust changes from normal to increased thickness with seamounts. The structure of the central Chilean forearc is addressed by Völker et al. This accretionary margin differs from the erosive margin off Central American, and is dissected by large canyons that transport terrigenous sediment into the trench. The Central American forearc has been extensively studied for its hydrological system. Thorwart et al. trace seismic signals generated by pore-pressure propagation associated with fluids rising from the slab trenchward of the seismogenic zone into the forearc. Such fluids ultimately form cold seeps at the seafloor typically above faults. Mau et al. and Karaca et al. document the large methane fluxes at submarine slump scars produced by seamount subduction. Geochemical evidence demonstrates a fluid contribution from subducted clay dewatering and the formation of seep carbonates from mixed pore water and seawater
(Mavromatis et al.). Carbonate cores investigated by Liebetrau et al. reveal frequent temporal changes in fluid compositions and downward growth of the cementation front at mud mounds. Absolute ages of seep carbonates by U/Th dating and correlation with the marine $\delta^{18} \mathrm{O}$ record suggest that major methane degassing events occurred during low sealevel stands as shown by Liebetrau et al. and Han et al. The latter contribution also suggests that seep carbonates may record their temperature of formation rather than the fluid source. Finally, a review by Suess on cold seeps and their manifestations places the results from offshore Costa Rica and southern Chile into a global context of seep research with emphasis on subduction zone settings.

Another set of papers addresses topics related to arc magma petrogenesis. Mutter et al. experimentally determine fluid-ocean crust element partition coefficients for a range of subduction $\mathrm{P}-\mathrm{T}$ conditions as a basis to understand geochemical subduction signals in arc volcanic rocks. Wehrmann et al. identify subducted sediment components in magmatic compositions from the Central American Volcanic Arc (CAVA) and the Chilean Southern Volcanic Zone (SVZ). Sediment-derived fluids cause Ba enrichment at the CAVA but $\mathrm{Pb}$ enrichment at the SVZ. A second paper by Wehrmann et al. reports magmatic sulfur and chlorine concentrations in mafic SVZ magmas and finds $\mathrm{Cl}$ inversely correlated with the degree of melting while concentrations are similar to the CAVA. Sulfur contents at the SVZ are lower than at the CAVA because of exsolution in the somewhat more evolved SVZ magmas. Portnyagin et al. show how volatile contents and degree of fractionation of recent Cerro Negro (Nicaragua) basaltic magmas changed during ascent through the crust and how decompression-induced volatile exsolution and associated crystallization act as driving forces for magma evolution.

Monitoring $\mathrm{SO}_{2}$ degassing at active volcanic vents has become a major contribution to hazard assessment in the SFB 574. Several papers of this special volume deal with degassing and volcanic hazards. Five years continuous monitoring at Turrialba (Costa Rica) has shown dramatic increase in $\mathrm{SO}_{2}$ flux for significant times prior to eruption, and together with simultaneously recorded seismicity, the data indicate a degassed shallow magma body presently beneath the volcano (Conde et al.). Bredemeyer and Hansteen have observed correlated 7-day periodicities in $\mathrm{SO}_{2}$ fluxes at Llaima and Villarrica volcanoes (Chile), which they interpret as the operation of an Earth tidal pump affecting the degassing process. Mora-Stock et al. document how the intensity of volcano seismicity and the rate of $\mathrm{SO}_{2}$ degassing changed systematically both weeks before and after the M8.8 Maule earthquake in 2010, suggesting that changes in regional stress state influenced volcanic processes. Another approach to assess volcanic hazards uses eruption records. Dzierma and Wehrmann apply statistical 
time series analyses to historical eruption records of CAVA volcanoes in order to determine future eruption probabilities. Gilbert et al. reconstruct the entire Holocene explosive eruption sequence of Lonquimay volcano (Chile) and apply the statistical approach to this record. The 200-ka-long time series of explosive eruptions at the CAVA obtained by SFB 574 work is used in climate models by Metzner et al. in order to scale representative global climate effects of highly explosive eruptions.

Finally, three papers consider volatile fluxes through entire subduction systems. Halama et al. investigate nitrogen flux with serpentinized slab mantle from the trench to high pressures and constrain the global subduction flux of nitrogen into deep mantle. Freundt et al. and Völker et al. integrate the available data from the SFB 574 and other research in their attempts to determine volatile budgets for the Central American and Chilean subduction zones, respectively.
Acknowledgments A major resource for success of the SFB was the excellent support of field work by scientists and technicians at institutions in the SFB research areas: Instituto Costarricense de Electricidad (ICE) and Universidad de Costa Rica; Instituto Nicaragüense de Estudios Territoriales (INETER), Nicaragua; Servicio Nacional de Estudios Territoriales (SNET), El Salvador; Instituto Nacional de Sismología, Vulcanología, Meteorología e Hidrología (INSIVUMEH), Guatemala; Servicio Nacional de Geología y Minería (SERNAGEOMIN), Chile; Universidad de Chile, Santiago, Chile; Universidad de Concepcion, Chile; Universidad de Valparaiso, Chile; Servicio Geológico Minero Argentino (SEGEMAR), Argentina; Universidad de Buenos Aires, Argentina. Marine expeditions for the SFB 574 benefitted greatly from the very efficient support by the crews of RV Meteor and RV Sonne. Many collaborating scientists such as from the US MARGINS program contributed to the achievements of the SFB. We particularly acknowledge those colleagues who gave their time and expertise for the indispensable peer reviews of the contributions presented in this special issue. 